
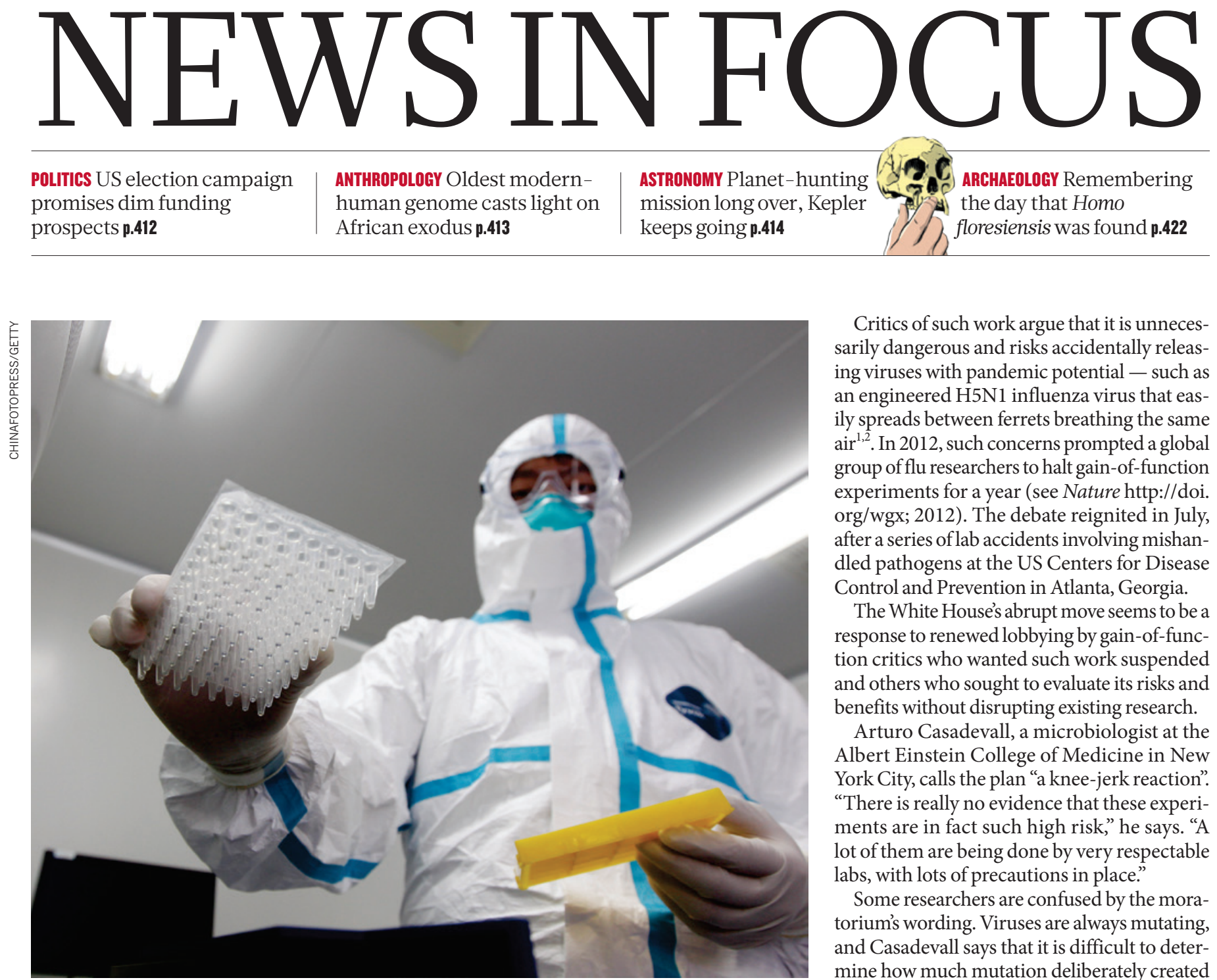

Outbreaks of influenza have prompted research into strains with pandemic potential.

BIOSECURITY

\title{
US suspends risky disease research
}

Government to cease funding gain-of-function studies that make viruses more dangerous, pending a safety assessment.

\section{BY SARA REARDON}

$\mathrm{T}$ The US government surprised many researchers on 17 October when it announced that it will temporarily stop funding new research that makes certain viruses more deadly or transmissible. The White House Office of Science and Technology Policy is also asking researchers who conduct such 'gain-offunction' experiments on influenza, severe acute respiratory syndrome (SARS) and Middle East respiratory syndrome (MERS) to stop their work until a risk assessment is completed leaving many unsure of how to proceed.

"I think it's really excellent news," says Marc Lipsitch, an epidemiologist at the Harvard School of Public Health in Boston, Massachusetts, who has long called for more oversight for gain-of-function research. "I think it's common sense to deliberate before you act."
Critics of such work argue that it is unnecessarily dangerous and risks accidentally releasing viruses with pandemic potential — such as an engineered $\mathrm{H} 5 \mathrm{~N} 1$ influenza virus that easily spreads between ferrets breathing the same air $^{1,2}$. In 2012, such concerns prompted a global group of flu researchers to halt gain-of-function experiments for a year (see Nature http://doi. org/wgx; 2012). The debate reignited in July, after a series of lab accidents involving mishandled pathogens at the US Centers for Disease Control and Prevention in Atlanta, Georgia.

The White House's abrupt move seems to be a response to renewed lobbying by gain-of-function critics who wanted such work suspended and others who sought to evaluate its risks and benefits without disrupting existing research.

Arturo Casadevall, a microbiologist at the Albert Einstein College of Medicine in New York City, calls the plan "a knee-jerk reaction". "There is really no evidence that these experiments are in fact such high risk," he says. "A lot of them are being done by very respectable labs, with lots of precautions in place."

Some researchers are confused by the moratorium's wording. Viruses are always mutating, and Casadevall says that it is difficult to determine how much mutation deliberately created by scientists might be "reasonably anticipated" to make a virus more dangerous - the point at which the White House states research must stop. The government says that this point will be determined for individual grants in discussions between funding officers and researchers.

One of the most prominent laboratories conducting gain-of-function studies is run by Yoshihiro Kawaoka, a flu researcher at the University of Wisconsin-Madison. In 2012, Kawaoka published a controversial paper ${ }^{1}$ reporting airborne transmission of engineered $\mathrm{H} 5 \mathrm{~N} 1 \mathrm{flu}$ between ferrets. He has since created an $\mathrm{H} 1 \mathrm{~N} 1$ flu virus using genes similar to those from the 1918 pandemic strain ${ }^{3}$, to show how such a dangerous flu could emerge. The engineered H1N1 was transmissible in mammals and much more harmful than the natural strain.

Kawaoka says that he plans to comply with the White House directive to halt current research once he understands which of his projects it affects. "I hope that the issues can be discussed openly and constructively so that important research will not be delayed indefinitely," he says.

But it seems that the freeze could be lengthy. The White House says that it will wait for 
- recommendations from the US National Science Advisory Board for Biosecurity (NSABB) and the National Research Council before deciding whether and how to lift the ban. The groups are expected to finish their work within a year. As Nature went to press, the NSABB was set to convene on 22 October, its first meeting in two years. Lipsitch, who will speak at the event, says that he will advocate for the development of an objective risk-assessment tool to evaluate individual research projects. In particular, he says, decision-makers should consider whether a gain-of-function study makes a contribution to a public-health goal, such as the prevention and treatment of flu, that could justify both the risk and the use of money that could be spent on safer research.

"There clearly are going to be instances where gain-of-function research is necessary and appropriate, and there are others where the opposite applies," says Ian Lipkin, a virologist at Columbia University in New York City. The need to understand the ongoing Ebola outbreak in West Africa and control its spread, for instance, emphasizes the importance of infectious-disease research - as well as the regulation of such work, Lipkin says. Although public worry about Ebola being transferred through the air is unfounded, researchers could make a case for the need to determine how the virus could evolve in nature by engineering a more dangerous version in the lab. "I think we should have some sort of guidelines in place before such experiments are even proposed," says Lipkin. Yet Ebola is not included in the White House's research-funding ban, and a spokesperson says that there are no plans to include it on the list.

One thing is certain, says Casadevall: the NSABB meeting is certain to see heated debate as scientists from all sides convene. "I hope they have enough room," he adds. mSEE EDITORIALP.403

1. Imai, M. et al. Nature 486, 420-428 (2012).

2. Herfst, S. et al. Science 336, 1534-1541 (2012).

3. Watanabe, T. et al. Cell Host Microbe 15, 692-705 (2014).

\section{US midterm elections offer little hope for science}

\section{November vote is unlikely to break a political stalemate that has squeezed research funding.}

\section{BY LAUREN MORELLO}

W hen US voters head to the polls on 4 November, they are poised to set in motion a major political shift that promises to intensify partisan strife over issues such as climate change, immigration and research funding. For the first time since 2006, Republicans are likely to win full control of the US Congress - having seized the House of Representatives in 2010, they are now predicted to take control of the Senate.

The development seems inauspicious for US researchers who depend on government funding. Prominent Republicans have repeatedly questioned the veracity of biological evolution and human-induced climate change, and party leaders' push for drastic spending cuts has resulted in across-the-board reductions known as sequestration, which slashed $5.1 \%$ from science agencies' budgets in 2013.

Yet in fact, the changing balance of power is expected to have little practical impact because Congress may not be able to do much of anything. Experts see little hope of breaking the political gridlock that has made the current Congress, which began in January 2013, arguably the least productive in modern history. "It doesn't matter what happens to the Senate," says Michael Lubell, director of public affairs for the American Physical Society in Washington DC. "The outcome is going to be the same."

Although Republicans already hold a commanding advantage in the House of Representatives, they are expected to win only a simple

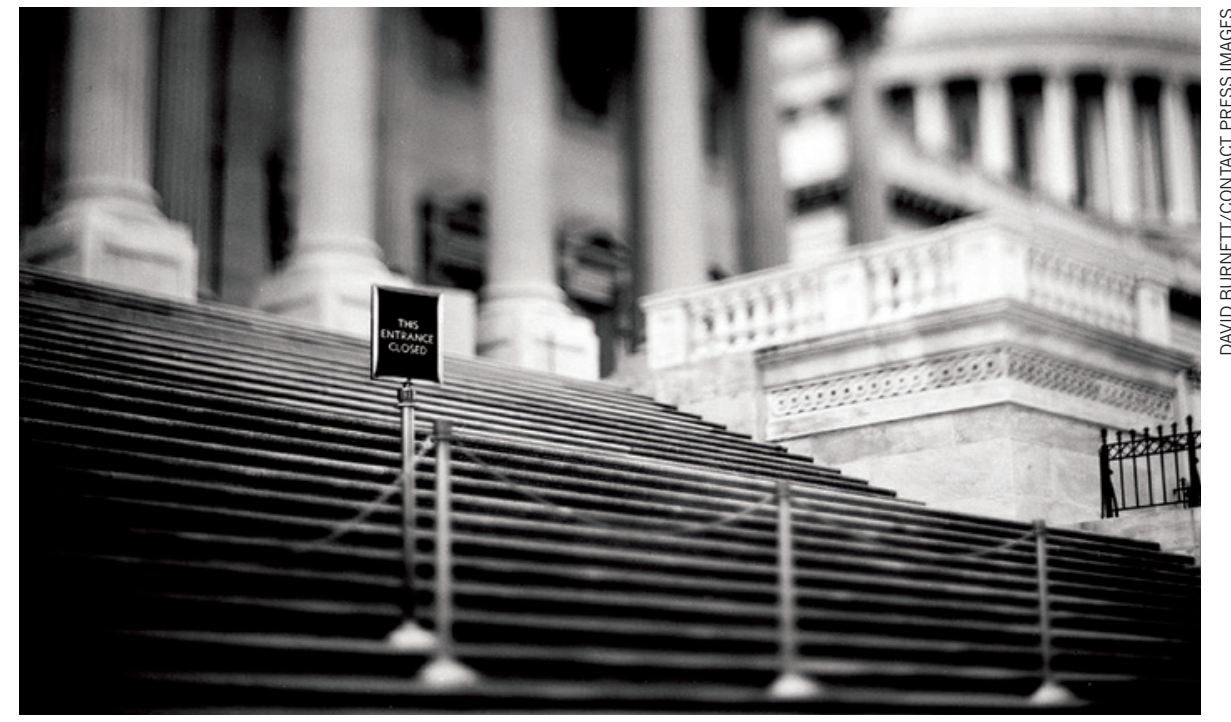

The deadlocked US Congress has been one of the least productive in modern history.

majority in the 100-member Senate, not the three-fifths majority that generally enables a party to pursue its legislative agenda without drawing any minority-party support.

That is a double-edged sword. Congress is unlikely to approve large increases in funding. But Republicans will have a hard time pushing through bills to enact the more extreme parts of their agenda - such as blocking new federal regulations to cut carbon emissions, or a plan to require the National Science Foundation to certify that all of its grants serve the 'national interest'. (That proposal, from the House science committee chairman Lamar Smith (Republican, Texas) is targeted mostly at funding for research in the social and behavioural sciences.) And even if such legislation were approved by the House and Senate, President Barack Obama would almost certainly exercise his veto power.

Relations are so bad between the two major parties that even the US pledge to help stop the Ebola outbreak in West Africa has sparked bickering. Earlier this month, Senator James Inhofe (Republican, Oklahoma) and several high-ranking Republicans in the House temporarily blocked Obama's request for 